\title{
INFLUENCE OF DEFICIT IRRIGATION AND PARTIAL DRY OF ROOT ZONE ON SQUASH CROP YIELD AND WATER USE EFFICIENCY
}

\author{
Abousrie Farag ${ }^{1}$ and Mari Isabel Ferrarie ${ }^{2}$
}

\section{ABSTRACT}

The main objectives of this research were to study the effects of sustained deficit irrigation (SDI) and partial drying of root zone (PRD) on yield and water use efficiency of squash (Cucurbita Pepo, L. Oto) crop. To fulfill these purposes, a field study was conducted in the experimental farm of Faculty of Agriculture, at Moshthor, Benha University, Egypt, for the two successive seasons of late summer (2016 and 2017), under both drip surface (DSI) and subsurface irrigation (SSDI) systems. Five irrigation treatments were undertaken. The first (FI-100\%) was corresponding to full crop water requirements ( $F W R$ ), and soil water deficit was replenished to field capacity when $50 \%$ of the available water was exhausted, depending on root depth which was predicted by a root depth model. The second treatment was corresponding to $80 \%$ of the FWR (SDI-80\%), the third one was corresponding to $70 \%$ of FWR (SDI-70\%), the fourth one was corresponding to $70 \%$ of the FWR and partial drying of root zone (SDI$70 \%+P R D)$, and in the last treatment (SDI-50\%), the crop was irrigated at $50 \%$ of full water requirement FWR. In the treatment (SDI-70\%+PRD), the root zone was irrigated partially but from alternate laterals. The results show that surface drip irrigation (DSI) resulted in lower WUE and lower yield of squash than the sub-surface drip irrigation (SSDI), although with the subsurface drip irrigation system water consumption is less than with the surface drip irrigation by $5 \%$. The treatment (FI-100\%) resulted in both the highest WUE and squash yield either with surface or sub-surface. The treatment SDI-80\% resulted in WUE and yield not significantly different from FI-100\%. SDI-70\%+PRD resulted in WUE and yield almost equal to those achieved with SDI-80\%.

Keywords: subsurface drip irrigation, sustainable deficit irrigation, surface drip irrigation and nutrient use efficiency.

1 Lecturer at Department of Agricultural and Bio-systems Engineering, Faculty of Agriculture, Benha University, Egypt. Abousrie.ahmad@fagr.bu.edu.eg

2 Professor, Department of Agronomy, Lisbon University, Portugal. 


\section{INTRODUCTION}

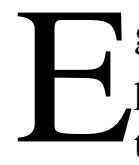

gypt is located within the dry desert belt, where the River Nile has played, a long time ago, an important role in converting a part of this desert to a wide green oasis. The amount of the Nile water, which is available for Egypt is about 55.5 thousand million cubic meters per year. However, according to the enormous increase in population, the quota of this water per each person became in 2018 is about $564 \mathrm{~m}^{3} /$ year (FAO, 2018). The agricultural sector consumes about $85 \%$ of the Nile water each year, with water losses upon its conveying from the High Dam until reaching the field estimated as $35 \%$ i.e. about 19.4 thousand million cubic meters /year. Also, about 2 thousand million cubic meters of the Nile water are lost by evaporation, in addition to 2.8 thousand million cubic meters that are lost through transpiration by weeds (FAO, 2018).

Better agricultural practices and upgraded understandings of water productivity could contribute to the fruitful management of a limited amount of water accessible for agricultural uses (Howell, 2001; Jones, 2004). On the other hand, over irrigation may harm soil aerations (Masto et al., 2009).

Deficit irrigation (DI, i.e. irrigation below the water requirements for maximum yield) is a technique for water-saving by which crops are subjected to a specific level of water stress either amid a specific period or through the entire growing season (Pereira et al., 2002). The primary objective of utilizing DI is to increase water use efficiency (WUE) by decreasing the quantity of applied water (Kirda, 2007).

In Egypt, summer squash is one of the most popular vegetable crops (Ibrahim and Selim, 2010). Egypt produced approximately 559600 ton, of squash, pumpkin and gourd with an average of 18.2 t.ha ${ }^{-1}$ (FAOSTAT, 2014).

In general, the application of drip irrigation significantly had increased the marketable squash fruits yield in addition to other irrigation systems. Also, it significantly had affected the vitamin C content, dry matter, carotenoids content and sugars (Rolbiecki, et al., 2014).

The fruit yield of squash grown in northern Egypt was significantly influenced by irrigation water amount has been studied by Amer (2011). Maximum yields, fruit numbers, diameters and lengths were acquired from 
well-watered treatments irrigated for full crop water requirements, or crop evapotranspiration $\left(E T_{c}\right)$. The estimated yield was increased at higher irrigation levels (100\% and $120 \%$ of estimated $\left.E T_{c}\right)$, and it diminished at lower irrigation levels (60\% and $80 \%$ of estimated $E T_{c}$ ). Also, WUE was diminished by excessive (1.25 and 1.5 of estimated $\left.E T_{c}\right)$ or deficit $(0.50$ and $0.70 E T_{c}$ ) irrigation treatments (Amer, 2011).

The current research aims at producing knowledge for saving water consumed in squash crop production, as well as, increasing WUE by using surface and subsurface drip irrigation integrated with SDI and PRD.

\section{MATERIAL AND METHODS}

\section{Experimental site.}

The experimental field has an arid climate and is located at latitude of $30^{\circ}$ $21^{\prime} 26^{\prime \prime} \mathrm{N}$ and longitude $31^{0} 13^{\prime} 15^{\prime \prime} \mathrm{E}$. It is about $15 \mathrm{~m}$ above sea level (asl) and it received rainfall in winter at a rate of about $22 \mathrm{~mm} /$ year $(r+17$ and r.IV) according to the Meteorological Weather Station of Faculty of Agriculture at Moshtohor, Benha University) installed recently, in the following referred as iMETOS station. The climate of the Egypt is BWh (hot dessert climate) according to Köppen (1936).

\section{Soil and water analyses}

The soil properties of the experimental site were analyzed physically and chemically according to the standard methods outlined by Klute (1986) and Page et al. (1982). Results of the analyses are shown in Tables 1 and 2. Also, the chemical analyses of the irrigation water were carried out according to the standard methods out lined by Page et al. (1982) and the results are illustrated in Table 3.

Table 1: Soil physical properties for different soil layers:

\begin{tabular}{|c|c|c|c|c|c|c|c|c|c|c|c|c|c|}
\hline \multirow{3}{*}{$\begin{array}{l}\text { Depth } \\
\text { (cm) }\end{array}$} & \multicolumn{4}{|c|}{ Particle size distribution (\%) } & \multirow{3}{*}{$\begin{array}{l}\text { Textural } \\
\text { class }\end{array}$} & \multirow{3}{*}{$\begin{array}{l}\text { SP } \\
(\%)\end{array}$} & \multirow{3}{*}{$\begin{array}{l}\Theta_{\mathrm{V} F C} \\
(\%)\end{array}$} & \multirow{3}{*}{$\begin{array}{l}\Theta_{\mathrm{VWP}} \\
(\%)\end{array}$} & \multirow{3}{*}{$\begin{array}{l}\text { AW } \\
(\%)\end{array}$} & \multirow{3}{*}{$\begin{array}{l}\text { BD } \\
\text { mg.m }\end{array}$} & \multirow{3}{*}{$\begin{array}{l}\text { PD } \\
\text { Mg.m }^{-3}\end{array}$} & \multirow{3}{*}{$\begin{array}{l}\text { TP } \\
(\%)\end{array}$} & \multirow{3}{*}{$\begin{array}{l}\text { K } \\
\text { cm.day }^{-1}\end{array}$} \\
\hline & \multicolumn{2}{|c|}{ Sand } & \multirow[t]{2}{*}{ Silt } & \multirow[t]{2}{*}{ Clay } & & & & & & & & & \\
\hline & Coarse & Fine & & & & & & & & & & & \\
\hline $0-20$ & 20.95 & 1.28 & 27.92 & 49.85 & Clay & 70.00 & 33.50 & 16.00 & 17.50 & 1.10 & 2.16 & 49.07 & 1.40 \\
\hline $20-40$ & 21.23 & 1.96 & 28.19 & 48.62 & Clay & 80.00 & 38.50 & 18.50 & 20.00 & 1.15 & 2.30 & $\mathbf{5 0 . 0 0}$ & 1.41 \\
\hline $40-60$ & 18.30 & 2.62 & 31.16 & 47.92 & Clay & 76.67 & 36.83 & 17.67 & 19.17 & 1.19 & 2.13 & 44.13 & 1.39 \\
\hline
\end{tabular}

Where $S P$ : Saturation percentage, $A W$ : available water, $\Theta_{V F C}$ and $\Theta_{V} W P$ : volumetric water content at field capacity and at wilting point $\left(\mathrm{m}^{3} / \mathrm{m}^{3}\right)$, respectively: $P D$ : particle density, $\mathrm{K}$ : saturated hydraulic conductivity, $B D$ : bulk density and $T P$ : total porosity 
Table 2: Soil chemical properties.

\begin{tabular}{cccccc}
$\begin{array}{l}\text { Depth } \\
(\mathrm{cm})\end{array}$ & $\mathrm{pH}$ & $\begin{array}{l}\mathrm{EC} \\
\left(\mathrm{dS} . \mathrm{m}^{-1}\right)\end{array}$ & $\begin{array}{l}\text { Total } \\
\text { nitrogen }(\%)\end{array}$ & $\begin{array}{l}\text { Available K } \\
\left(\mathrm{mg} . \mathrm{L}^{-1}\right)\end{array}$ & $\begin{array}{l}\text { Available P } \\
\left(\mathrm{mg} . \mathrm{L}^{-1}\right)\end{array}$ \\
\hline $0-20$ & 8.42 & 2.59 & 0.11 & 389.7 & 41.1 \\
$20-40$ & 7.19 & 2.22 & 0.09 & 390.1 & 39.6 \\
$40-60$ & 7.7 & 3.63 & 0.08 & 370.6 & 37.2 \\
\hline
\end{tabular}

Table 3: Chemical properties of the irrigation water

\begin{tabular}{c|ccccccc}
\hline $\begin{array}{l}\text { Water } \\
\text { property }\end{array}$ & $\begin{array}{l}\text { Electrical } \\
\text { conductivity (EC) }\end{array}$ & $\mathrm{pH}$ & $\begin{array}{l}\text { Total } \\
\text { nitrogen }\end{array}$ & $\mathrm{Na}$ & $\mathrm{Cl}$ & $\mathrm{Mg}$ & $\mathrm{NO}_{3}$ \\
\hline Unit & $\mathrm{dS} . \mathrm{m}^{-1}$ & & $\%$ & $\mathrm{mgL}^{-1}$ & $\mathrm{mgL}^{-1}$ & $\mathrm{mgL}^{-1}$ & $\mathrm{mgL}^{-1}$ \\
Value & 2.65 & 7.34 & 0.001 & 219 & 418 & 0.48 & 0.16 \\
\hline
\end{tabular}

\section{Crop and irrigation treatments}

Squash crop (Cucurbit apepo, Oto sp) was cultivated in clay soil at the Farm of Faculty of Agriculture, Benha University during the summer of 2016 and 2017. The experimental was divided into 8 plots: each of them had 3 rows conducted at distances of $50 \mathrm{~cm}$ between each two successive plants and $1 \mathrm{~m}$ between rows. The length of each row was $12 \mathrm{~m}$ and the numbers of rows was 24 and the discharge of emitters (GR) was $41 \mathrm{hr}^{-1}$ under 0.7 bar. Four plots were used for surface drip irrigation (SDI) and the other four plots were used for the sub-surface drip irrigation (SSDI). The experimental design was as shown (Figure 1). In each of the 8 subplots, with 3 rows each, we considered 3 repetitions, for yield and WUE analysis; for logistic reasons they were together in one sub-plot.

Soil water at $100 \%$ FI must be kept up over half of the available soil water (AW) to avoid detrimental water deficit (Hess et al., 1997), meaning that the soil water depletion fraction ( $p$ ) for the prevention of stress is considered as 0.5 (Savva and Frenken, 2002; Allen et al., 1998).

\begin{tabular}{|c|c|c|c|c|c|c|c|}
\hline B & C & H & G & A & D & A & F \\
\hline F & E & A & E & C & F & C & H \\
\hline D & H & B & G & D & B & G & E \\
\hline
\end{tabular}

Fig (1): The randomize distribution of treatments by excel. where: 
$\mathrm{A}=100 \%$ FI under SDI, $\mathrm{B}=\mathrm{DI} 80 \%$ under SDI, $\mathrm{C}=\mathrm{DI} 70 \%+\mathrm{PRD}$ under SDI, D=DI 50\% under SDI, E= 100\% FI under SSDI, F= DI $80 \%$ under SSDI, $\mathrm{G}=\mathrm{DI} 70 \%+\mathrm{PRD}$ under SSDI and $\mathrm{H}=\mathrm{DI} 50 \%$ under SSDI

The irrigation treatments were as follows:

FI-100\%: Full irrigation. Soil water deficit was replenished to field capacity when $50 \%$ of the available water $(\mathrm{p}=0.5)$ was depleted. In order to estimate irrigation depths, root depth was determined at each irrigation event by a root growth model. Soil water depletion was estimated from the sum of $\mathrm{ET}_{\mathrm{a}}$ since last irrigation by the model later described (equation 2, 3 and 4);

DI-80: Deficit irrigation, which received $80 \%$ of the irrigation depth of FI$100 \%$;

DI-70\%+PRD: Deficit irrigation, which received $70 \%$ of the irrigation depth of FI-100\% with partial drying of root zone (PRD) from alternate laterals;

DI-50\% - Deficit irrigation, which received 50\% of FI-100\%.

\section{Meteorological data}

Meteorological data were measured by using an iMETOS station that is maintained by the University of Benha, which includes a temperature and a relative humidity sensor, a rain gauge, a leaf wetness sensor, a soil temperature sensor, a global radiation sensor and a wind speed sensor to calculate reference evapotranspiration $\left(E T_{o}\right)$.

\section{Crop water requirements}

Crop water requirements for non-stressed crop corresponds to crop evapotranspiration which is the product of reference evapotranspiration $\left(E T_{o}\right)$ by a crop coefficient, $K_{c}$.

$E T_{o}\left(\mathrm{~mm} \mathrm{day}^{-1}\right)$ was calculated by Penman-Monteith (equation 1, Allen $\boldsymbol{e t}$ al., 1998 \& 1996).

$$
E T_{o}=\frac{0.408 \Delta\left(R_{n}-G\right)+\gamma \frac{900}{T+273} U_{2}\left(e_{s}-e_{a}\right)}{\Delta+\gamma\left[1+0.34 U_{2}\right]}
$$

where $R_{n}$ is net radiation at the crop surface [ $\mathrm{MJ} \mathrm{m}^{-2}$ day $^{-1}$ ], $G$ soil heat flux density $\left[\mathrm{MJ} \mathrm{m}^{-2}\right.$ day $\left.^{-1}\right], T$ mean daily air temperature at $2 \mathrm{~m}$ height $\left[{ }^{\circ} \mathrm{C}\right]$, $U_{2}$ wind speed at $2 \mathrm{~m}$ height $\left[\mathrm{m} \mathrm{s}^{-1}\right], e_{s}$ saturation vapor pressure [kPa], $e_{a}$ 
actual vapor pressure $[\mathrm{kPa}], e_{s}-e_{a}$ saturation vapor pressure deficit $[\mathrm{kPa}], \Delta$ slope vapor pressure curve $\left[\mathrm{kPa}{ }^{\circ} \mathrm{C}^{-1}\right]$ and $\gamma$ psychometric constant $\left[\mathrm{kPa}^{\circ} \mathrm{C}^{-1}\right]$. The $K_{c}$ values for squash that we considered were: initial stage 0.5 , mid stage 0.95 and late stage 0.75 . Also, the duration of the growth stages (days), plant height $(\mathrm{m})$ and maximum root depth $(\mathrm{cm})$ were taken from Allen et al. (1998) usually known as FAO 56: initial stage as 25 days, development stage as 35 days, mid stage as 35 days, late stage as 25 days. Plant height as $0.3 \mathrm{~m}$ and maximum root depth, ranging between $0.6 \mathrm{~m}$ and $1 \mathrm{~m}$, were taken from Allen et al. (1998).

\section{Irrigation scheduling}

Because we used as irrigation depth for no stress treatment (full irrigation) the full readily available water $(R A W)$ capacity in soil, the depths of irrigation application $\left(\mathrm{d}_{\mathrm{i}}, \mathrm{mm}\right)$ for FI-100\% were calculated as the RAW by the following equation:

$$
R A W=p T A W
$$

where $p(0-1)=$ the fraction of total available soil water $(T A W)$ that can be depleted from the root zone before water stress is expressed, i.e., a reduction in ET occurs.

$$
T A W=1000\left(\Theta_{F C}-\Theta_{W P}\right) Z_{r}
$$

where

$T A W=$ the total available soil water in the root zone $(\mathrm{mm})$,

$\theta_{F C}=$ the water content at field capacity $\left(\mathrm{m}^{-3} \mathrm{~m}^{-3}\right)$,

$\Theta_{W P}=$ the water content at wilting point $\left(\mathrm{m}^{-3} \mathrm{~m}^{-3}\right)$,

$Z_{r}=$ the root depth $(\mathrm{m})$.

The total irrigation depth (including application losses) (I) was obtained as:

where

$$
I=\frac{T A W}{E_{i}}
$$

$$
\begin{aligned}
& I=\text { the applied irrigation depth (mm) } \\
& E_{i}=\text { the irrigation efficiency }(\%)
\end{aligned}
$$

The irrigation interval (i) was obtained as:

$$
i=\frac{R A W}{E T_{c}}
$$


Since $R A W$ and $E T_{c}$ will vary over the growing season, the irrigation depth and the interval of irrigation will also change.

To estimate the effective root depth $\left(Z_{r}\right)$ we considered root depth growth with time calculated using the procedure described by Borg and Grimes (1986), as follows:

$$
Z_{r}=Z_{r m}\left[0.511+0.511 \operatorname{Sin}_{(\mathrm{rad})}\left[3.03 \frac{D A P}{D T M}-1.47\right]\right]
$$

where:

$Z_{r}$ is the root depth in $\mathrm{cm}, Z_{r m}$ is the maximum root depth of the crop in $\mathrm{cm}$ (from table and according to soil type), DAP is the number of days after planting, DTM is the number of days to maximum root depth. According to Plauborg et al, (1996) the root depth growth rate is $1.2 \mathrm{~mm} \mathrm{day}^{-1}$ for grass and $1.5 \mathrm{~mm} \mathrm{day}^{-1}$ for other crops, until maximum effective root depth has been reached and this information can be used alternatively. We assumed that the root depth for squash mustn't be less than $5 \mathrm{~cm}$.

\section{Stress coefficient Ks.}

It is assumed that the crop was subjected to water stress in all treatments, except FI-100\%. In this case, the crop coefficient can't be used alone for calculating the actual evapotranspiration $\left(E T_{a}\right)$ of squash crop, but the stress coefficient $K_{s}$ has to be also used for this aim:

$$
K_{s}=\left\lfloor\frac{T A W-D_{r}}{T A W-R A W}\right\rfloor
$$

where $K s$ is the stress coefficient and $D r$ is soil water depletion ( $\mathrm{mm}$ ).

In conclusion, the adjusted or actual evapotranspiration $\left(E T_{a}, \mathrm{~mm}^{\mathrm{d}} \mathrm{d}^{-1}\right)$ was estimated by the following equation:

$$
E T_{a}=E T_{C} K_{S}
$$

Consequently

$$
E T_{a}=E T_{0} K_{c} K_{s}
$$

\section{Soil water content measurements and estimation}

Soil water content $\left(\theta_{v}\right)$ was measured three times during the growth season of squash. Each time, two soil samples were taken, before irrigation and 48 $\mathrm{h}$ after irrigation, for each treatment. Therefore, it was possible to compare between the predicted water and actual (measured) water content in order to analyze the adequacy of the parameters for estimating water use. 
The available soil water $(A S W)$ was estimated from the water balance equation, as:

$$
A S W_{i+1}=A S W_{i}+\Delta S
$$

where the storage change $\Delta S$ between day $\mathrm{i}$ and $\mathrm{i}+1$ is given by:

$$
\Delta S=P+I-D P-E T_{a}
$$

where runoff and capillary rise were neglected and deep percolation $(D P)$ is considered null, whenever $\theta_{v}$ is $<\theta_{v}$ at $F C$, and is equal to the difference between water in soil and $\theta_{V} \times Z_{r}$ (total water in root zone at field capacity, $A S W_{F C}$ ), for $\theta_{V}>\theta_{V}$ at FC . In summary:

$$
A S W_{i+1}=A S W_{i}+P+I-D P-E T_{a}
$$

where $D P=0$ if $\theta_{V} \leq \theta_{F C}$ and $D P=A S W_{i}-A S W_{F C}$ if $\theta_{V}>\theta_{F C}$. In order to be compared with measured $\theta_{v}$, the estimated $A S W$ is divided by $Z_{r}$.

\section{Yield-salinity relationship}

The electrical conductivity for soil $\mathrm{EC}_{\mathrm{e}}$ was $2.54 \mathrm{dS} \mathrm{m}^{-1}$ i.e. lower than the electrical conductivity threshold i.e. the $\mathrm{EC}_{\mathrm{e}}$ threshold at which the yield of squash crop begins to decrease, which according to Allen et al (1998) is $4.7 \mathrm{dS} \mathrm{m}^{-1}$.

The leaching requirement $(L R)$ was calculated according to the following equation (Rhoades, 1974).

$$
L R=\left(E C_{i w} /\left[\left(5 \times E C_{e}\right)-E C_{i w}\right] \times 100\right.
$$

where: $L R=$ leaching requirement $(\%)$,

$E C_{i w}=$ the electrical conductivity of irrigation water $\left(\mathrm{dS} . \mathrm{m}^{-1}\right)$,

$E C_{e}=$ the maximum tolerance $\mathrm{EC}$ for crop $\left(\mathrm{ds} . \mathrm{m}^{-1}\right)$.

Since the $E C_{e}$ of squash is $4.7 \mathrm{dS} \mathrm{m}^{-1}$ and $\mathrm{EC}_{\mathrm{e}}$ was $2.65 \mathrm{dS} \mathrm{m}^{-1}$, the $L R$ is estimated as $12.22 \%$.

\section{Yield and WUE}

The squash yield was taken twice every weak at marketable size after 60 days from planting. The all plants were taken from each of the repetitions in the 8 sub-plots (Figure 1). The WUE efficiency was calculated by dividing the yield $(\mathrm{Mg})$ by the seasonal actual evapotranspiration $(\mathrm{mm})$.

\section{Statistical analysis}

Three replicates from each treatment were analyzed statistically by Spss program version 19 at significant level of $0.5 \%$ (P. value 0.5\%). ANOVA 
and LSD tests were carried out on data to show the significant difference values among the means.

\section{RESULTS AND DISCUSSION}

Relation between available soil water (ASW) and the applied depth of water Irrigation frequency varied according to the soil moisture content dependent on the water balance in soil. Generally, irrigation was conducted as the soil moisture reached the critical value for soil water content as established above (lower limit of RAW) determined from the soil water balance. Table 4 and fig. 2 and 3 show that the irrigation depths varied according to stage of plant growth, as well as, with the changes in meteorological conditions, which determined the different quantities of water losses due to evapotranspiration (as percolation was neglected or assumed as null) with surface and sub-surface drip irrigation systems.

Table 4: The (previewed) schedule for squash irrigation depths with average values for the time intervals $\left(E T_{c}\right.$, Precipitation $(P), K c$, root depth $(\mathrm{mm})$ and applied irrigation depth for each system $(I)$ ) considering full irrigation.

\begin{tabular}{|c|c|c|c|c|c|c|}
\hline \multirow{2}{*}{ Date } & \multirow{2}{*}{$\begin{array}{c}E T_{c} \\
\left(\mathbf{m m}^{-d^{-1}}\right)\end{array}$} & \multirow{2}{*}{$\begin{array}{c}\boldsymbol{P} \\
(\mathbf{m m})\end{array}$} & \multirow{2}{*}{$\boldsymbol{K}_{c}$} & \multirow{2}{*}{$\begin{array}{c}Z_{r} \\
(\mathbf{m m})\end{array}$} & \multicolumn{2}{|c|}{$I(\mathbf{m m})$} \\
\hline & & & & & SDI & SSDI \\
\hline 10-Aug & 1.93 & 0.00 & 0.50 & 50 & 20.00 & 20.00 \\
\hline 14-Aug & 2.09 & 0.00 & 0.53 & 50 & 7.23 & 6.85 \\
\hline 17-Aug & 2.02 & 0.00 & 0.55 & 50 & 8.46 & 8.34 \\
\hline 20-Aug & 2.01 & 0.00 & 0.58 & 50 & 10.70 & 10.21 \\
\hline 24-Aug & 2.27 & 0.00 & 0.61 & 71 & 10.52 & 10.42 \\
\hline 28-Aug & 2.11 & 0.00 & 0.64 & 105 & 7.30 & 6.97 \\
\hline 31-Aug & 2.59 & 0.00 & 0.66 & 133 & 9.91 & 9.67 \\
\hline 4-Sep & 2.17 & 0.00 & 0.69 & 172 & 11.32 & 11.01 \\
\hline 7-Sep & 2.26 & 0.00 & 0.71 & 203 & 6.20 & 5.99 \\
\hline 10-Sep & 2.22 & 0.00 & 0.73 & 234 & 16.31 & 15.71 \\
\hline 15-Sep & 2.32 & 0.00 & 0.77 & 284 & 13.78 & 13.46 \\
\hline 20-Sep & 2.18 & 0.00 & 0.81 & 328 & 18.64 & 17.94 \\
\hline 26-Sep & 2.30 & 0.00 & 0.85 & 371 & 17.04 & 16.71 \\
\hline 1-Oct & 2.51 & 0.00 & 0.89 & 395 & 22.21 & 21.24 \\
\hline 8-Oct & 2.17 & 0.00 & 0.94 & 409 & 21.84 & 21.43 \\
\hline 15 -Oct & 2.42 & 0.00 & 0.95 & 397 & 19.79 & 18.75 \\
\hline 22-Oct & 2.03 & & 0.95 & 361 & 17.80 & 16.45 \\
\hline & 160.37 & & & & 239.06 & 231.14 \\
\hline
\end{tabular}




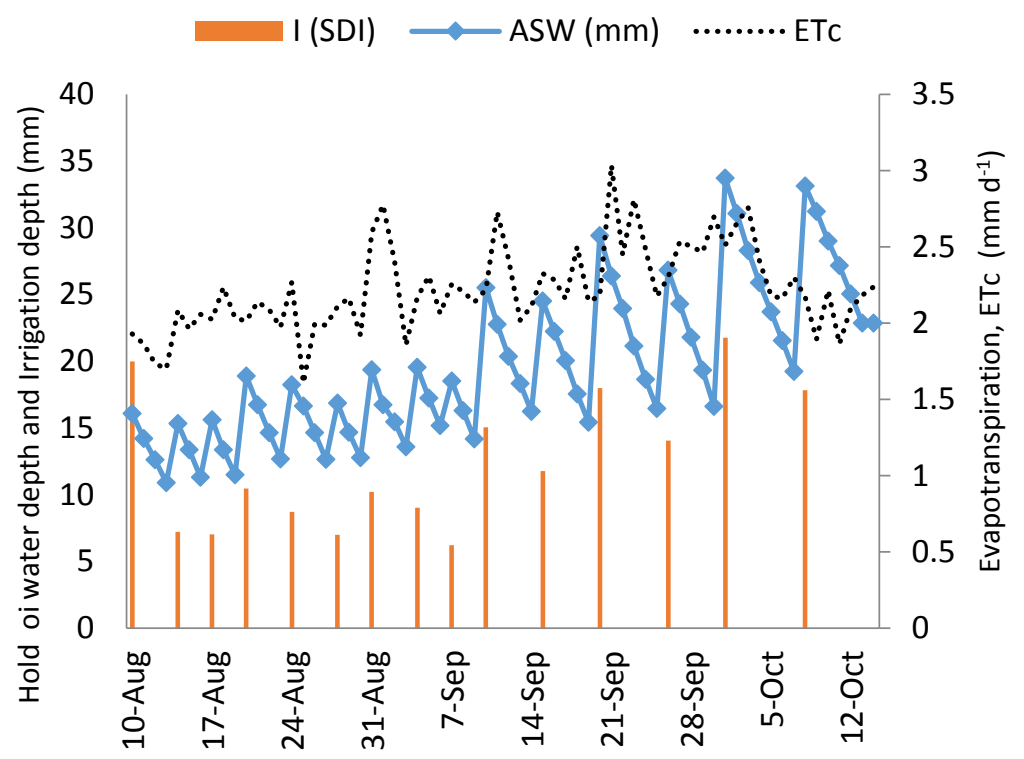

Fig (2): $E T_{c}$, available soil water (mm, equation 12) and applied irrigation depth $(I, \mathrm{~mm})$ under surface drip irrigation (SDI) during the growth season, for FI-100\%
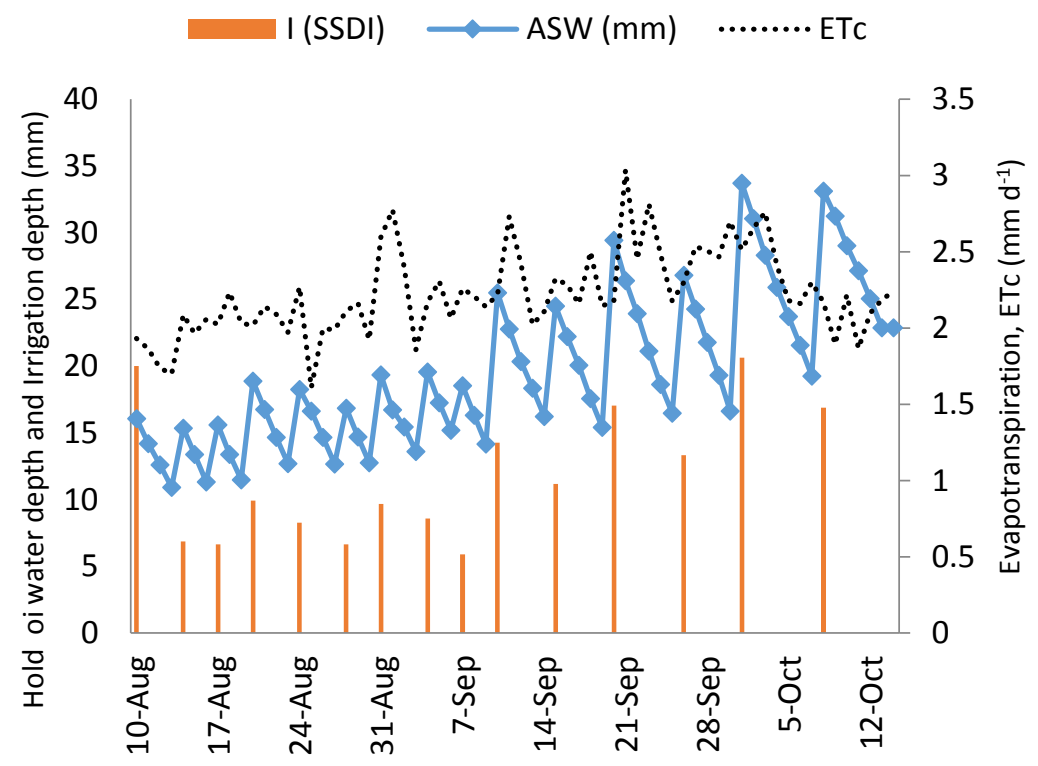

Fig (3): $E T_{c}$, available soil water (mm, equation 12) and applied irrigation depth $(I, \mathrm{~mm})$ under sub-surface drip irrigation (SSDI) during the growth season, for FI-100\% 
Figures 5 and 6 show the seasonal course of $I, A S W$ and $K_{c}$ under surface drip and sub-surface drip irrigation systems, respectively. The values of $I$ and ETC were not steady due to the changes in the meteorological data and root growth.

By following up the procedure for calculating the amount of water required for each irrigation, described in Materials and Methods, the soil moisture is kept almost constant on average, i.e., within the limits correspondent to $R A W$. In other words, the water to be applied exactly would provide optimum conditions for plant growth and save water by avoiding over irrigation.

\section{The measured and modelled soil water depletion}

We analyzed the seasonal course of observed soil water status in relation to modeled values (expressed in $\mathrm{mm}$ ) and in relation to the thresholds such as the upper and lower edge of $R A W$ and the lower limit of TAW (wilting point) as shown in Figs 4 a to $d$ and Figs 5 a to d, respectively for surface (SDI) and subsurface irrigation (SSDI).

This comparison allows an overall judgment about the simple model used to estimate ET, as well as an understanding about the stress levels obtained in relation to the ones we aimed to apply, assuming the soil parameters estimated for $\theta_{F C}$ and $\theta_{W P}$ as correct.

In relation to the first aspect, there is a good agreement between measured and modeled values, in all cases, except in DI-80 of SSDI (Fig 5b).

Furthermore, in both cases of full irrigation (Fig 4a and 5a) some deep percolation occurred, as expected, as leaching requirement was included in irrigation depths. In both cases, plants were never under water stress, as $A S W$ never reached the lower limit of $R A W$.

For DI, $A S W$ decreased to values progressively lower as the treatments corresponded to lower percentages of water applied, attaining values close to the WP, for the $50 \%$ treatment. These results suggest that the values taken as $K c$ seem appropriate and, on the other side, the treatment $50 \%$ is the lower possible reduction without major risks for survival. This is true for both irrigation systems (SDI and SSDI). 


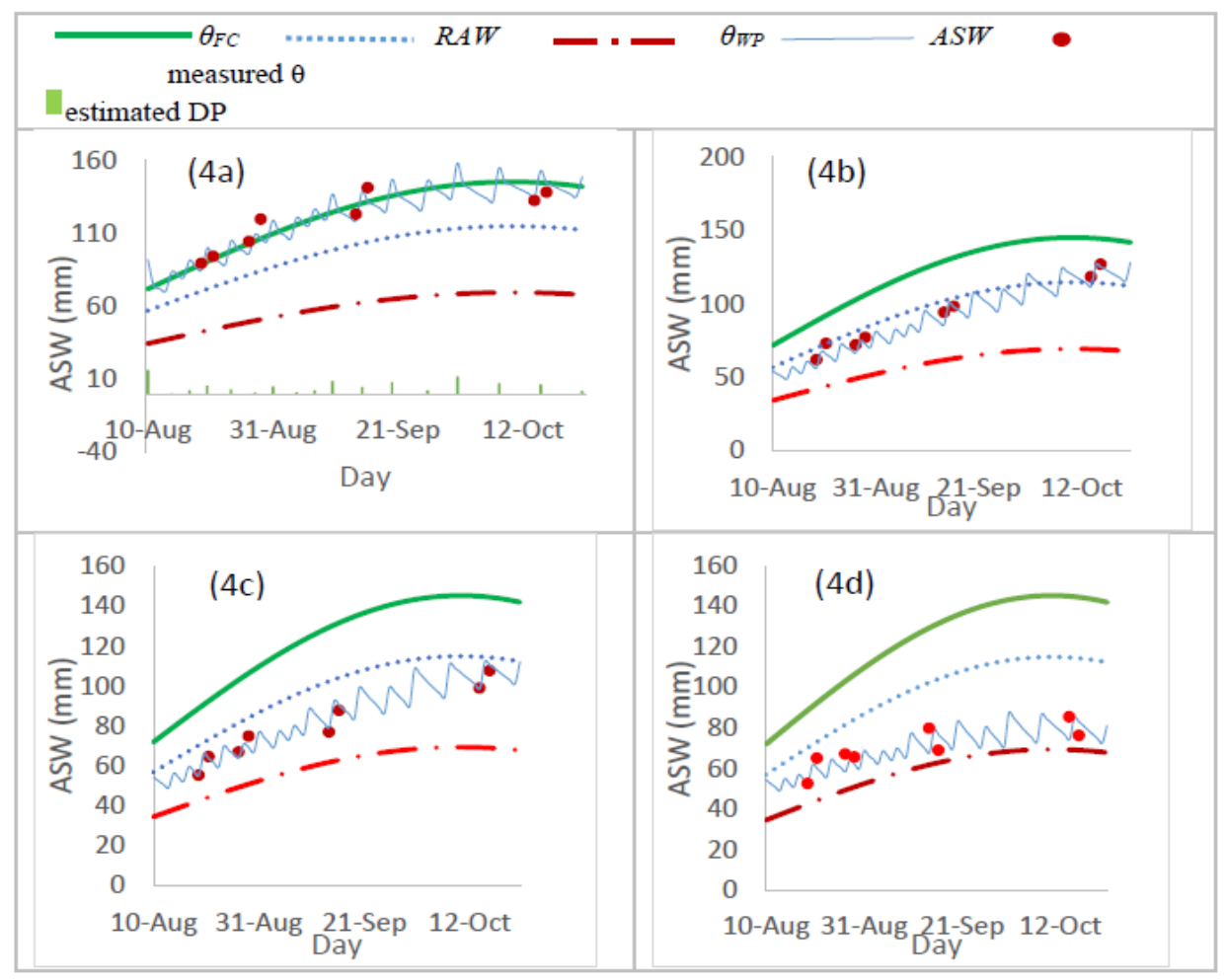

Fig (4): Seasonal course of available soil water $A S W$ estimated (lines) and measured (dots), in addition to the lines correspondent to FC, lower limit of RAW and WP. Figures a, b, c and d correspond to 100\%, 80\%, 70\%-

PRD and 50\% under SDI, respectively.

\section{Estimating water stress on plants (crop stress factor, Ks)}

The crop was grown in conditions of limited water except treatment FI$100 \%$. The results illustrated by Figs. 6 a to $7 \mathrm{~d}$ show the seasonal course of the stress factor Ks estimated from equation 8 and $E T_{a}$ under $100 \%, 80 \%$ and $70 \%-\mathrm{PRD}$ and $50 \%$ of $\mathrm{ET}_{\mathrm{C}}$, respectively. The values of $K s$ show that there was no stress on plants with $100 \%$ of $E T_{c}$ but some stress was present in other treatments. For instance, $K s$ was decreasing between 0.8 and 0.5 in early season and it arrived to 1 (no stress) in late season for treatment $80 \%$. For $70 \%$-PRD, Ks was relatively stable ranging between 1 at the beginning of season and 0.7 at late season, (after irrigation) and between 1 at the beginning of season and 0.2 at late season (before irrigation). For DI-50\%, $K s$ was decreasing along the season ranging from around 0.5 but arriving to values as low as 0.1 . 

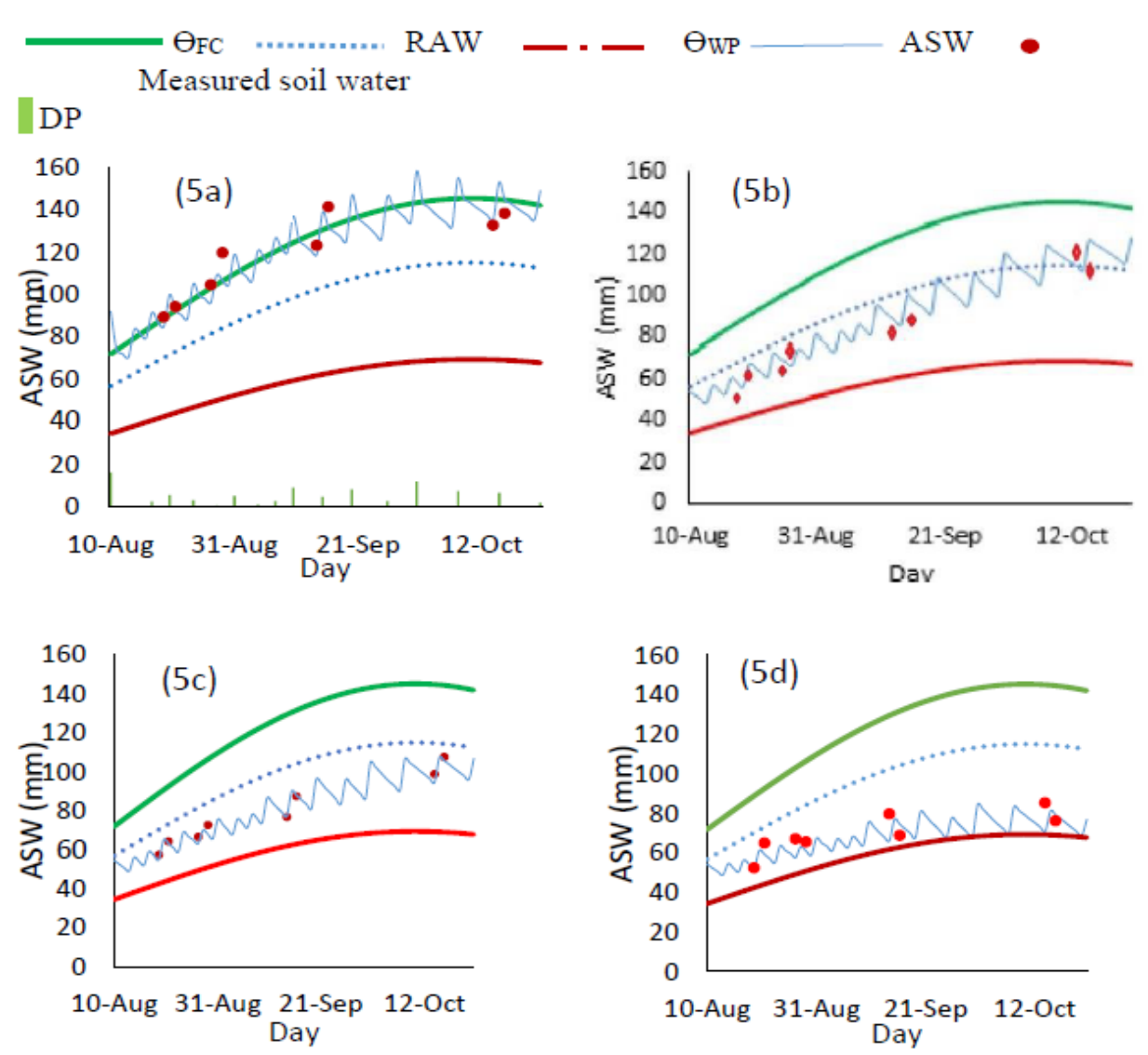

Fig (5): Seasonal course of available soil water ASW estimated (lines) and measured (dots), in addition to the lines correspondent to FC, lower limit of RAW and WP. Figures a, b, c and d correspond to 100\%, 80\%, 70\%-PRD and 50\% under SSDI, respectively.

Overall, the results above show that the values of $K_{c}$ considered (section 3.5 ) and estimated $K s$ have an acceptable precision, because the points in Figs. 4 and 5, with one exception as mentioned above, are similar to the ones observed. Besides, no deep percolation was estimated for the deficit irrigation treatments. These results also suggest that the soil parameters used were correct. Also, results consistent with expectation Ks in some cases. Ks function would provide values that with time correspond on average to approximately the reduction in irrigation depth. However, this is not the case to the treatment DI-50\%. Eventually this can be explained by a lack of adequacy of Ks model as Ks decreases, as discussed in Ferreira (2017). 

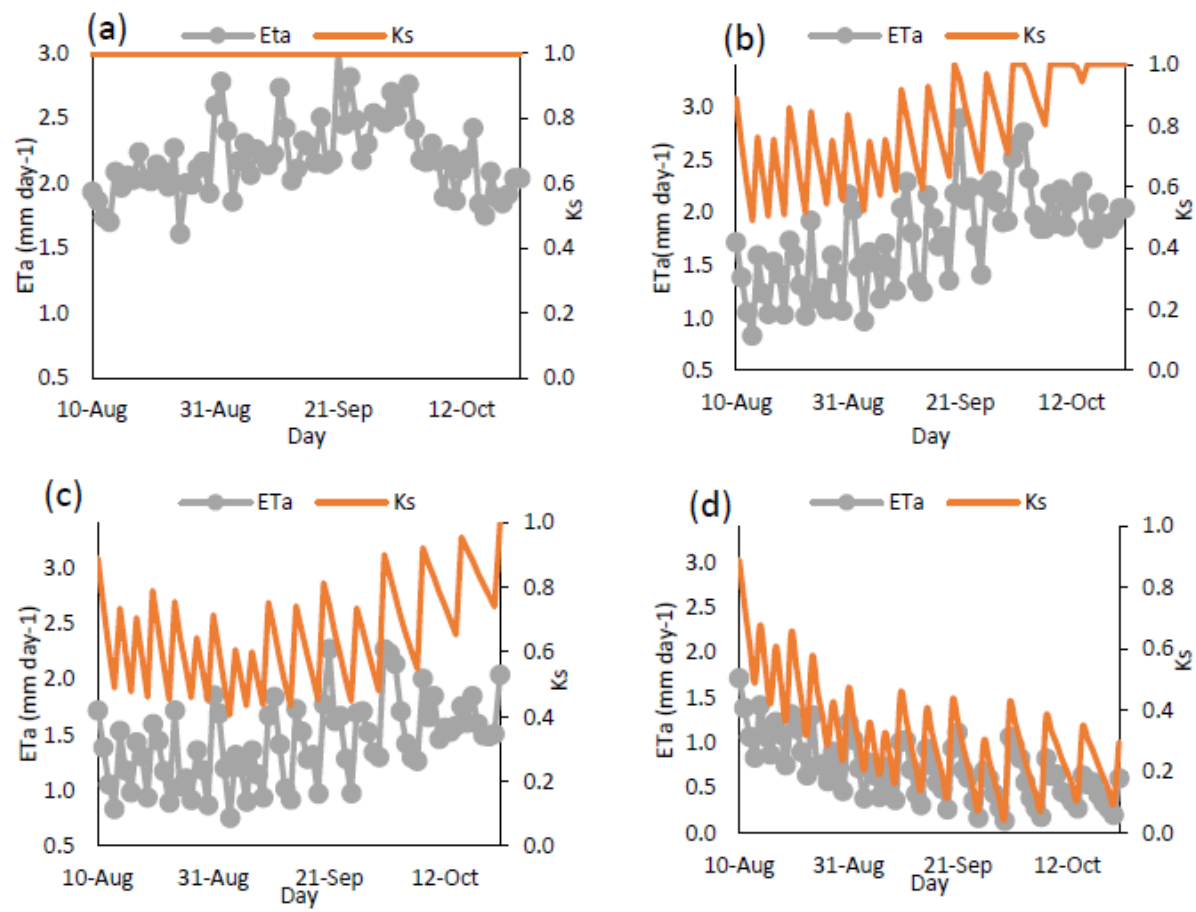

Fig (6): Actual evapotranspiration $E T_{a}$ and stress factor $K_{S}$. Figures a, b, c and d correspond to $100 \%, 80 \%, 70 \%+$ PRD and $50 \%$ under surface drip irrigation (SDI).

\section{Squash yield and water use efficiency (WUE)}

Surface drip irrigation resulted in lower values of both WUE and yield of squash than the sub-surface drip irrigation, as data in Table 5 and Figs. 8 and 9, although the sub surface drip irrigation consumed lower quantities of irrigation water than the surface drip irrigation, by $5 \%$. It is worth to indicate that application of the irrigation water at $100 \%$ of estimated optimum crop requirements resulted in the highest squash yield. This occurred with drip irrigation either for surface or sub-surface. The treatment DI-80\% gave values of both WUE and yield not significantly different from those due to FI-100\%. The treatment DI-70\%+PRD resulted in values of both WUE and yield again not significantly different to those achieved due to DI-80\%. DI-50\% resulted in the clearly lower values of yield and WUE mainly in the case of surface drip irrigation system. The treatment DI-70\% for surface drip irrigation resulted in a WUE lower than the one achieved with DI-50\% for both surface an especially sub-surface 
drip irrigation, which suggests again an advantage of SSDI and a possible disadvantage of PRD, due to the costs involved. However, there are practical disadvantages to consider in SSDI systems because of the maintenance of the drippers. These results agree with Amer, 2011.
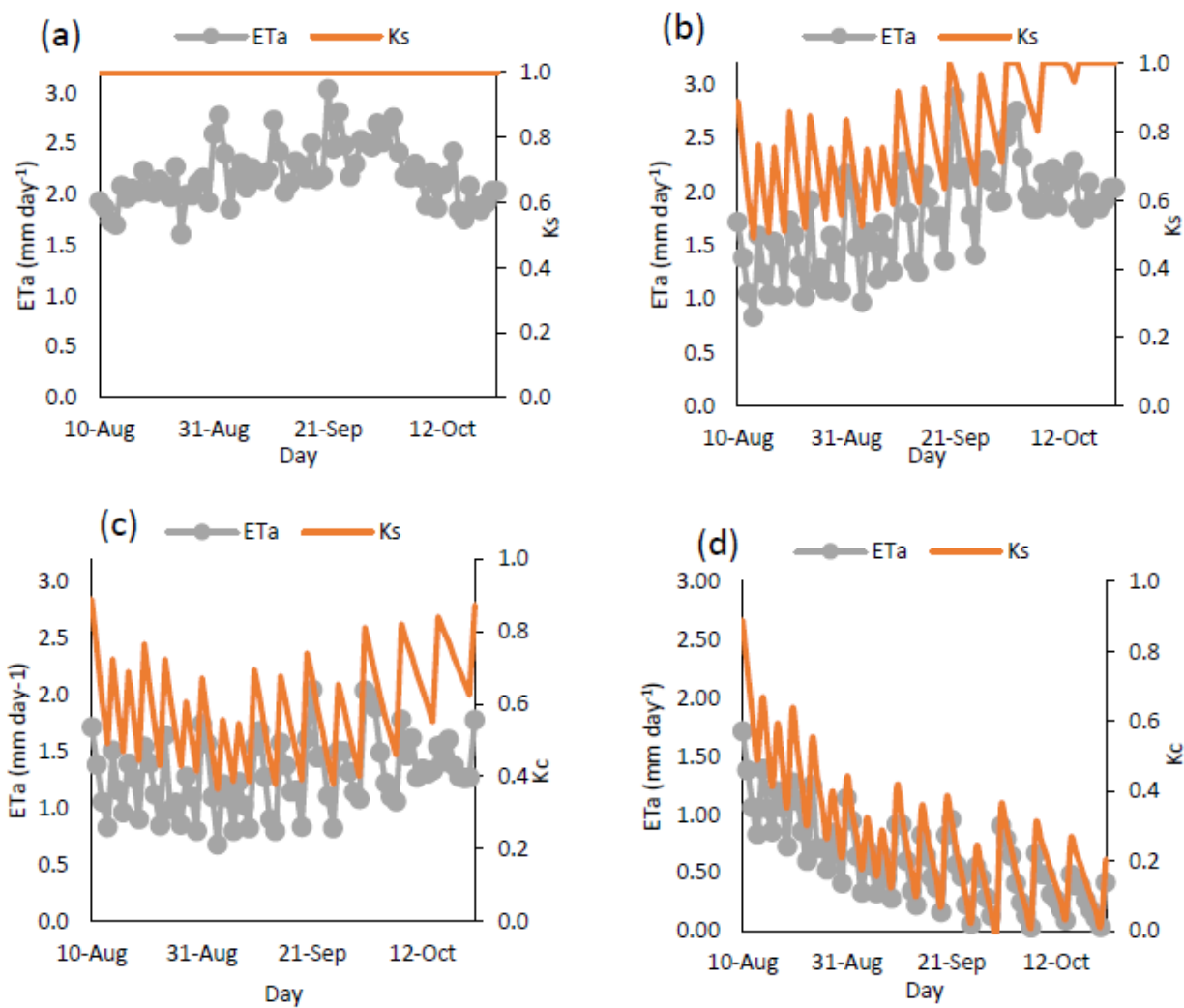

Fig (7): Actual evapotranspiration $E T_{a}$ and stress factor $K_{S}$. Figures a, b, c and d correspond to $100 \%, 80 \%, 70 \%+\mathrm{PRD}$ and $50 \%$ of $E T_{c}$ under subsurface drip irrigation (SSDI).

In general, the average values of WUE under SSDI were higher than under SDI. The highest values were $6.675 \mathrm{~kg} \mathrm{~m}^{-3}$ and $6.23 \mathrm{~kg} \mathrm{~m}^{-3}$ under SSDI at FI-100\% and DI-80\%, respectively and $6 \mathrm{~kg} \mathrm{~m}^{-3}$ under SDI at FI-100\%. The lowest values were 3.43 at DI-50\% respectively under SDI. The average values of yield for SSDI were above those for SDI by $7.26 \%, 12 \%$, $16.07 \%$ and $24.5 \%$ respectively for FI-100\%, DI-80\%, DI-70\%+PRD and DI-50\%, indicating a larger advantage of SSDI for more intensive water stress. 
Table 5: Squash yield and water use efficiency (WUE) under surface and sub-surface drip irrigation for different treatments. Percentages were calculated in relation to FI- $100 \%$.

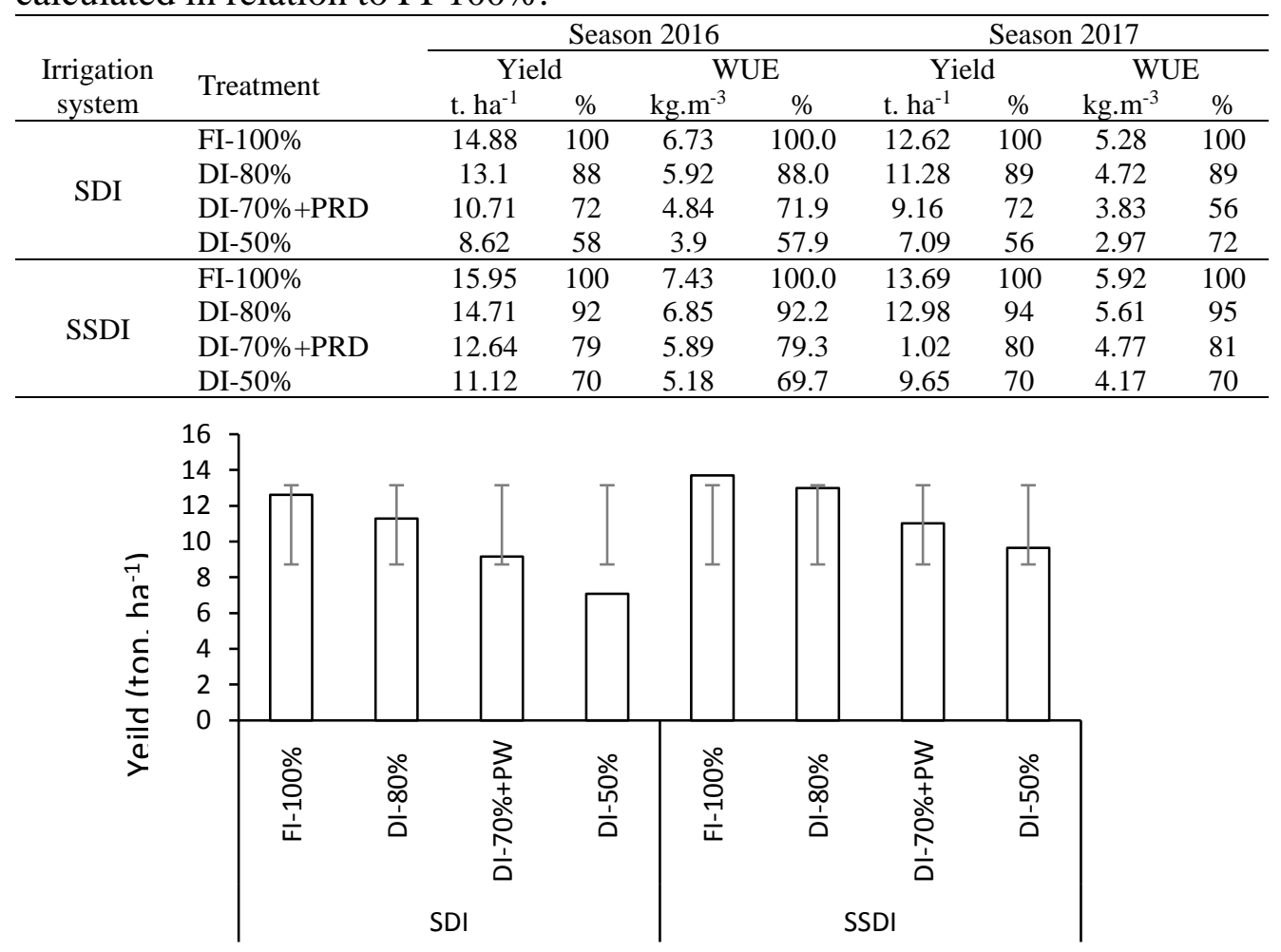

Fig (8): Yield of squash crop under surface and sub-surface drip irrigation systems at different irrigation strategies.

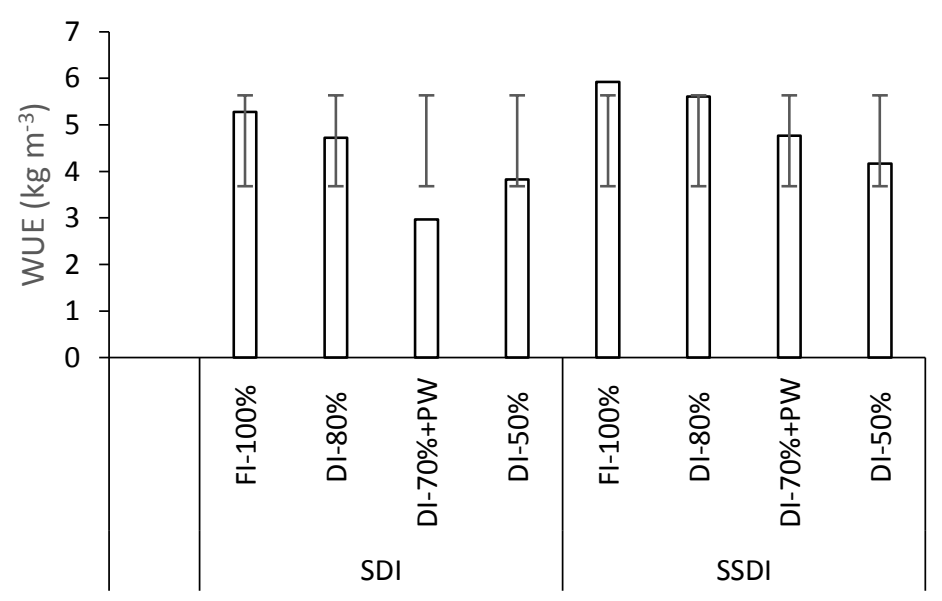

Fig (9): WUE of squash crop under surface and sub-surface drip irrigation systems at different irrigation strategies. 
A NOVA test only displayed significant differences between values of yield due to the different applied water depths and surface irrigation systems for the treatment DI-50\%. For all other treatments (DI-70\%+PRD, DI-80 and DI-100\%) it didn't show any significant difference at $\mathrm{P}$ value 0.05 , but for WUE values there were not any significant differences between the mean of values.

The statistical analysis shows that the differences between surface and subsurface irrigation systems are significant for yield ( $\mathrm{p}$ value is 0.046 ) and for WUE ( $\mathrm{p}$ value is 0.016 ).

Another interpretation of these result is by inferring that estimated $K s$ is not correct. However, the similarities between measured water content and estimated (eq 12) suggests this is not the case.

\section{CONCLUSIONS}

The comparison between the seasonal course of observed and modelled soil water status for $100 \%$ FI suggests that the variables and parameters used to model actual ET are adequate. All together the output seemed to fit with the results of the observations, but we cannot discriminate between adequacy of $E T_{o}$ and the values used for the coefficients $K_{c}$ and $K_{s}$. However, due to the fact that there was a good quality control of variables used for $E T_{o}$ estimation and also due to the fact that usually uncertainties are higher for $K_{c}$, we assume that $K_{c}$ values used are correct. We also assume that $K_{s}$ values estimated as described were generally correct.

The comparison between the FC and WP lines and the available soil water also reinforces the general adequacy of the model and the irrigation control, as well as the adequacy of soil parameters and root depth used.

The yield was not significantly decreased at DI- $80 \%$ and DI-70\% but it was significantly decreased at DI-50\%, But there weren't any significant differences between WUE values.

The achieved values of highest squash yield and WUE were found for subsurface drip irrigation in relation to surface irrigation. The results suggest the advantage of SSDI in terms of yield and WUE, increases in case of more severe stress. 
For the deficit irrigation treatments, the comparison between the reduction in yield which was noticed (but never lower than 44\%) and the $K_{s}$ estimated, which arrived to very low values suggests values for $K_{y}$ lower than expected.

We should also stress that no significant advantage of PRD could be observed.

\section{A KNOWLAGENT}

We thank ASRT and ERANETMAD for their support of this study, which carried out under the project of "Water Saving in Agriculture: technological developments for the sustainable management of limited water resources in the Mediterranean area".

\section{REFERENCES}

Allen, R. G. (1996). Assessing integrity of weather data for use in reference Evapotranspiration estimation. J. Irrig. Drain. Eng. ASCE 122(2): 97-106.

Allen, R. G., Pereira, L. S., Raes, D. and Smith, M. (1998). Crop evapotranspiration - Food and Agriculture Organization. Food and Agriculture Organization of the United Nations.

Amer, K. H. (2011). Effect of irrigation method and quantity on squash yield and quality. Agricultural Water Management, 98(8), 1197 1206.

Borg, H., and D.W. Grimes. 1986. Depth development of roots with time: An empirical description. Trans. ASAE 29:194-197

FAO. (2018.). AQUASTAT. Retrieved 3 12, 2018, from http://www.fao.org/NR/WATER/AQUASTAT/main/index.stm

FAOSTAT (2014). Food and Agriculture Organization (FAO). http://faostat.fao.org

Ferreira, M. I. (2017). Stress coefficients for soil water balance combined with water stress indicators for irrigation scheduling of woody crops. Horticulturae 3 (2), 38; doi:10.3390/horticulturae3020038 
Hess, M., Bill, M., Jason, S., John, S. (1997). Oregon State University Western Oregon Squash Irrigation Guide, vol. 541. Department of Bioresource Engineering, Corvallis, OR, pp. 737-6304.

Howell, T.A. (2001). Enhancing water use efficiency in irrigated agriculture. Agronomy Journal 93, 281-289.

Ibrahim, E., and Selim, E. (2010). Effect of irrigation intervals and antitranspirant (kaolin) on summer squash (Cucurbita pepo L.) growth, yield, quality and economics. J. Soil Sci. and Agric. Engineering, Mansoura Univ.., 1. 883-894.

Jones, H.G. (2004). What Is Water Use Efficiency? In: Bacon, M.A. (Ed.), Water Use Efficiency in Plant Biology. Blackwell Publishing, Oxford, UK, pp. 27-41

Kirda, C. (2002). Deficit Irrigation Scheduling Based on Plant Growth Stages Showing Water Stress Tolerance. Deficit Irrigation Practices. FAO Corp. Doc. Rep. 22, pp.-10 (Rome)

Klute, A. (1986). Methods of soil analysis. Part I. Physical and mineralogical methods. Second edition. Agronomy Series no. 9, ASA, Madison, Wis.

Köppen, W. (1936). Das geographische System der Klimate, in: Handbuch der Klimatologie, Band 1, Teil C., edited by: Köppen, W. and Geiger, R., Gebr. Borntraeger, Berlin, 1-44, 1936.

Masto, R. E., Chhonkar, P. K., Singh, D., and Patra, A. K. (2009). Changes in soil quality indicators under long-term sewage irrigation in a sub-tropical environment. Environmental Earth Sciences, 56(6), 1237-1243.

Page, A.L., Miller, R.H. and Keeney, D.R. (1982) Methods of Soil Analysis. Part 2. Chemical and Microbiological Properties. American Society of Agronomy. In Soil Science Society of America, Vol. 1159. 
Pereira, L.S., Oweis, T. and Zairi, A., (2002). Irrigation management under water scarcity. Agricultural Water Management 57, 170-206.

Plauborg, F., Andersen, M.N., Heidmann, T. and Olesen, J.E. (1996). Markvand: A decision support system for irrigation scheduling. Proc. Of the International conference on Evapotranspiration and Irrigation Scheduling. San Antonio, Texas 3-6 Nov. p. 527-535.

Rhoades, J.D., (1974). Drainage for salinity control. In: van Schilfgaarde, J. (Ed.), rainage for Agriculture. Agronomy Monograph No. 17. SSSA, Madison, WI, pp. 433-461.

Rolbiecki, R., Rolbiecki, S., Wichrowska, D., Wojdyla, T., Ptach, W., and Chmura, K. (2014). Effects of drip irrigation of summer squash cultivated on the light soil. Retrieved 8 17, 2017.

Savva, A. P. and Frenken K. (2002). Crop Water Requirements and Irrigation Scheduling. Irrigation Manual Module 4, FAO SubRegional Office for East and Southern Africa, Harare.

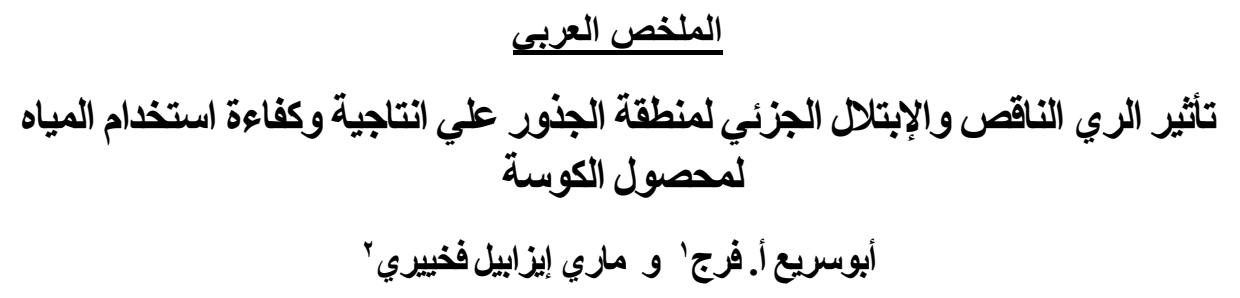

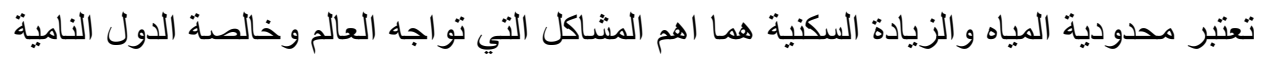

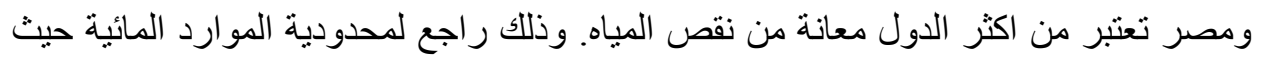

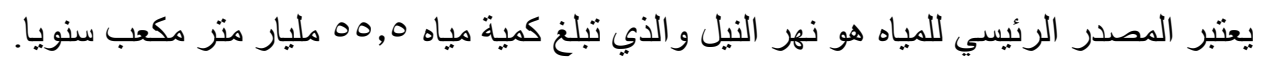

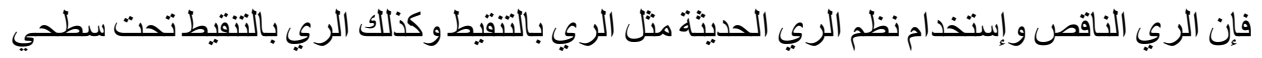

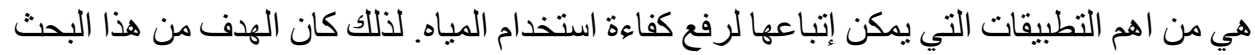

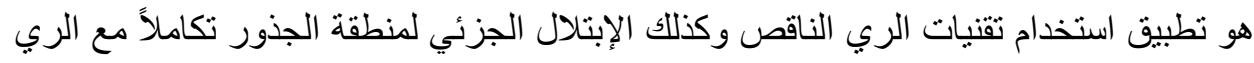
بالتنقيط فوق السطح وتحت السطح.

\footnotetext{
ا قسم هنسة النظم الزراعية والحيوية _كلية الزراعة - جامعة بنها

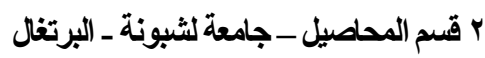


حيث تم إجر اء هذه الدراسة علي محصول الكوسة حيث يعتبر من أهم محاصيل الخضر الإقتصادية

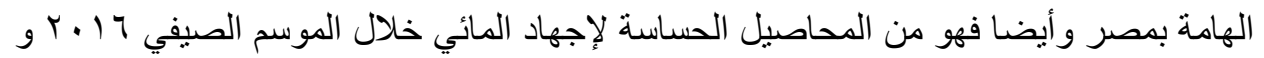

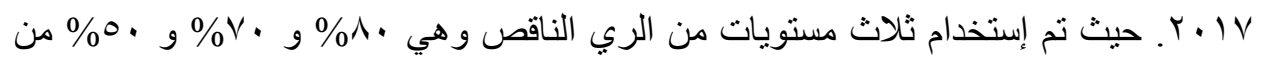

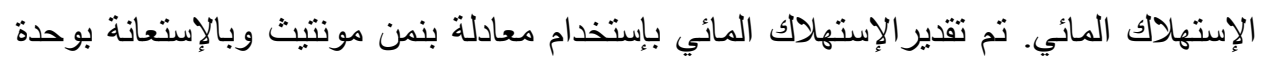

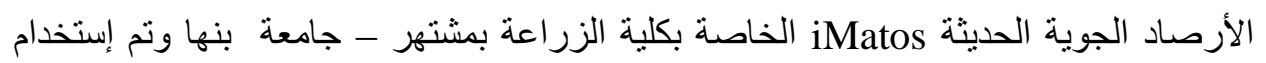
الموديل الخاص بنمو الجذر (Borg and Grimes 1986) (لجنة). وكذلك تم إستخدام تقنية الإبتلال الجزئي لمنطقة الجذور مع المعاملة • V \% و وميع هذه المعاملات نم تطبيقها تحت نظامي الري بتنقيط السطحى وتحت السطحي. حيث أوضحت اهم النتائج

ان محصول الكوسة حساس لنقص الرطوبة حيث أظهرة النتائج إنخفاض الإنتاج مع زيادة الإجهاد

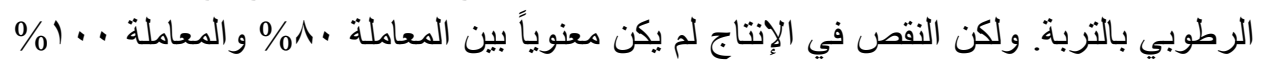

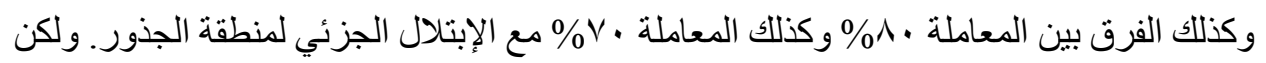
المعاملة • 0\% أظهرت فروق معنوية بينها وبين باقي المعاملات. علي الرغم من أن نظام الري بالتنقيط تحت السطحي يستهلاك كمية مياه اقل من الري بالتنقيط السطحي الا أن الري بالتنقيط تحت النطي الري بلفي تفوق عن الري بالتنقيط السطحي.

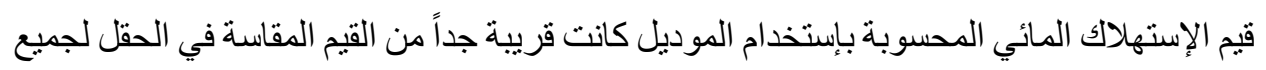

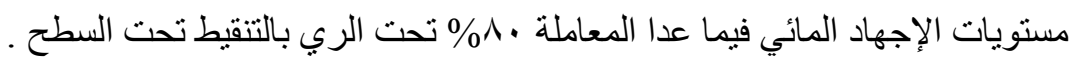

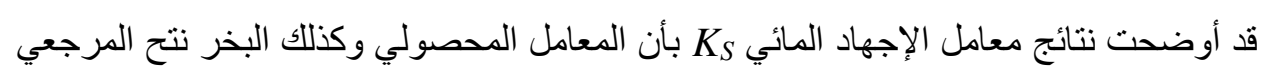

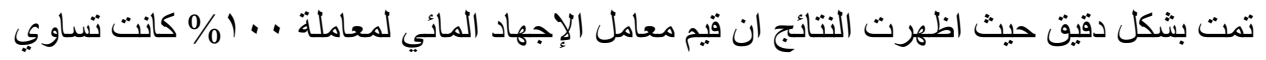

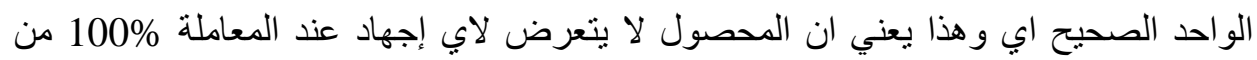

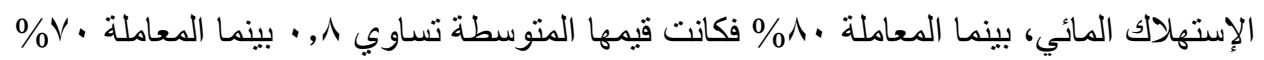

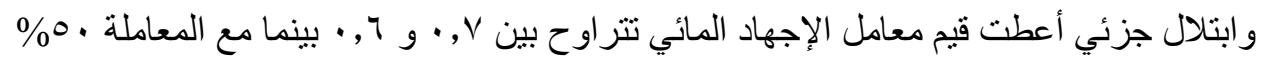

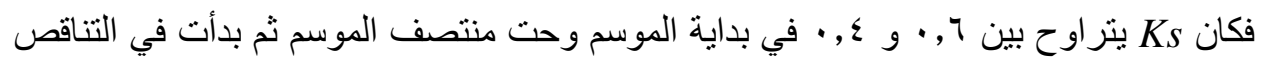

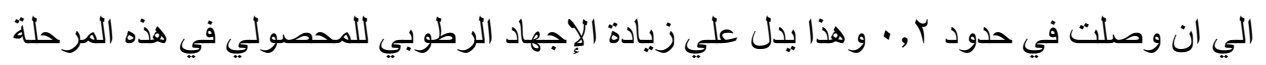

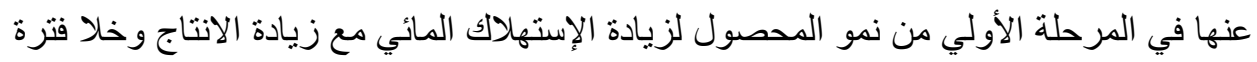
جمع المحصول. أظهرت نتائج كفاءة استخدام المياه للري ان الفروق بين المعاملات لم تكن كبيرة فيما عدا مع معاملة

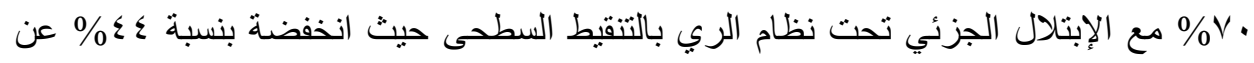

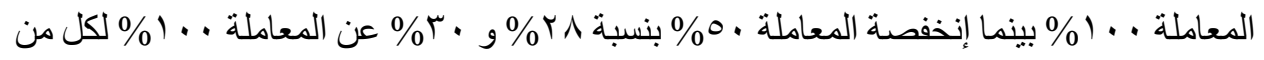
نظامي الري بالتقبط السطحي وتحت السطحي علي التو الي. بينما كان الإنخفاض في كفاءة استخدام 


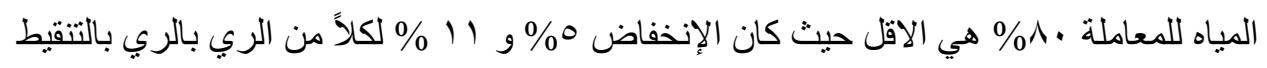
السطحي وفوق السطح علي النو الي.

اوضحت نتاج الإنتاجية لمحصول الكوسة تفوق الري بالتنقيط تحت السطح عن الري بالتنقيط

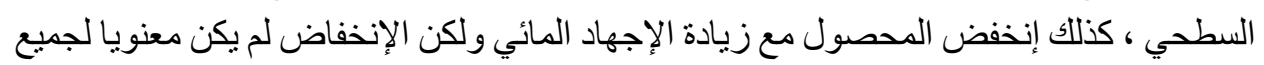

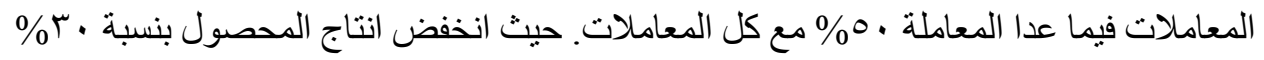

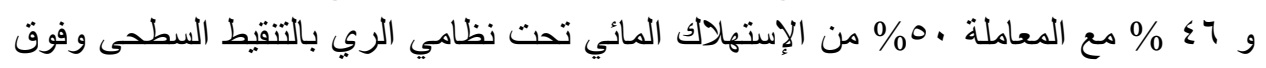
السطحى علي التو الي. 